\title{
Rancang Bangun Sistem Monitoring Arus Beban pada Gardu Distribusi Menggunakan Short Message Service
}

\author{
Ignatius I Wayan Rexci Indra Parmana ${ }^{1}$, Cok Gede Indra Partha ${ }^{2}$, Ngakan Putu Satriya Utama ${ }^{3}$
}

\begin{abstract}
- distribution substation is the main component of the electricity system. PLN as a provider of electricity needs in Indonesia are still using conventional method in monitoring the load current on the distribution substation to come to the location and retrieve data. Load current monitoring system is an instrument that is integrated in the distribution substation. Load current value is read and converted by the sensor, time and date information in real time display on LCD. Implementation of the load current monitoring system carried on $\mathrm{KA-0298}$ distribution substations that supply the Electrical Engineering Laboratory of the Udayana University. This instrument can monitor load current by commands sent via SMS. SMS command sent by the code "CEKARUS" can be received and responded to by the load current monitoring system with the result of SMS replies load curret value information $R$ phase, $S$ phase, $T$ phase and phase $N$ at distribution substation. Data logger system of the instrument can be used to record load current changes in the distribution substation. The load current notification system provides a warning SMS if there is load current disruption in distribution substations.
\end{abstract}

Intisari- Gardu distribusi merupakan komponen utama dari sistem distribusi tenaga listrik. PLN sebagai penyedia kebutuhan listrik di Indonesia masih menggunakan cara konvensional dalam memonitoring arus beban pada gardu distribusi dengan datang ke lokasi dan mengambil data. Sistem monitoring arus beban merupakan perangkat yang diintegerasikan pada gardu distribusi. Nilai arus beban yang dibaca dan dikonversi oleh sensor, informasi waktu dan tanggal secara real time ditampilkan pada LCD. Pengimplementasian sistem monitoring arus beban dilakukan pada gardu distribusi KA-0298 yang menyuplai Laboratorium Teknik Elektro Universitas Udayana. Perangkat ini dapat melakukan monitoring arus beban berdasarkan perintah yang dikirimkan melalui SMS. Perintah SMS yang dikirim dengan kode "CEKARUS" dapat diterima dan direspon oleh sistem monitoring arus beban dengan hasil balasan SMS informasi nilai arus beban fasa $R$, fasa $S$, fasa $T$ dan fasa $N$ pada gardu distribusi. Sistem data logger pada perangkat dapat digunakan untuk merekam perubahan arus beban pada gardu distribusi. Sistem notifikasi arus beban memberikan SMS peringatan jika terjadi gangguan arus beban pada gardu distribusi.

${ }^{1}$ Mahasiswa, Program Studi Teknik Elektro Fakultas Teknik Universitas Udayana, Br. Padangtawang, Canggu, Kuta Utara, Badung, Bali, Indonesia (telp: 081338421461; e-mail: wrexci@gmail.com)

${ }^{2}$ Dosen, Program Studi Teknik Elektro Fakultas Teknik Universitas Udayana, Jl. Tukad Badung XII B / 9 B Denpasar, Bali, Indonesia (telp: 082147566789; e-mail: c@unud.ac.id)

${ }^{3}$ Dosen Program Studi Teknik Elektro Fakultas Teknik Universitas Udayana, Jl. Sedap Malam Gang Alamanda No. 9 Kebon Kuri Kelod Kesiman, Denpasar, Indonesia (telp: 08113811221; e-mail:ngakansatriya@ee.unud.ac.id)

Ignatius I Wayan Rexci Indra Parmana: Rancang Bangun Sistem Monitoring...
Kata Kunci : SMS, Gardu Distribusi, Monitoring, PLN

\section{PENDAHULUAN}

Gardu distribusi merupakan komponen dari sistem distribusi tenaga listrik yang memegang peranan penting pada kontinyuitas suplai tenaga listrik ke konsumen. Pemeriksaan fisik dan pengukuran arus beban pada gardu distribusi harus dilakukan secara berkala sebagai langkah pemantauan (monitoring) gardu distribusi untuk mencegah terjadinya gangguan pada gardu distribusi. Monitoring yang baik dibutuhkan pengawasan secara realtime [1].

Bagian Operasi dan Pemeliharaan merupakan bidang bentukan PLN yang memiliki tugas memonitoring arus beban gardu distribusi secara rutin. Kenyataan di lapangan, petugas Bagian Operasi dan Pemeliharaan mengalami kendala dalam melaksanakan tugasnya, karena selama ini monitoring arus beban pada gardu distribusi masih menggunakan cara konvensional yaitu dilakukan dengan datang ke lokasi dan langsung mengambil data.

Solusinya adalah dengan perancangan sebuah alat monitoring yang dapat dikontrol langsung oleh pihak PLN dengan menggunakan layanan pesan singkat/SMS (Short Message Service). SMS ini sangat cocok digunakan untuk sistem pengontrolan wireless real time karena kecepatan pengiriman data, efisiensi dan jangkauannya luas. Layanan SMS ini masih perlu dihubungkan ke suatu perangkat kontrol untuk dapat melakukan monitoring piranti listrik dari jarak jauh. Dalam penelitian ini dilakukan suatu perancangan sistem monitoring arus beban pada gardu distribusi menggunakan short message service.

\section{DESAIN SISTEM}

\section{A. Pemodelan Sistem}

penjelasan dari pemodelan sistem yang dirancang adalah sebagai berikut

1. User atau petugas akan mengetikkan SMS sesuai dengan kode yang telah ditentukan yaitu CEKARUS.

2. Pesan singkat terlebih dahulu akan dikirim ke Short Message Service Centre (SMSC).

3. SMSC akan mengirim pesan singkat ke modul GSM. Pesan yang diterima modul GSM kemudian diverivikasi mikrokontroler, apabila kode yang dikirim tidak sesuai maka mikrokontroler akan mengabaikan instruksi tersebut. Instruksi akan dilakukan jika kode yang dikirim sesuai dengan isi program yang dirancang pada mikrokontroler. Setelah instruksi dilaksanakan, maka mikrokontroler akan 


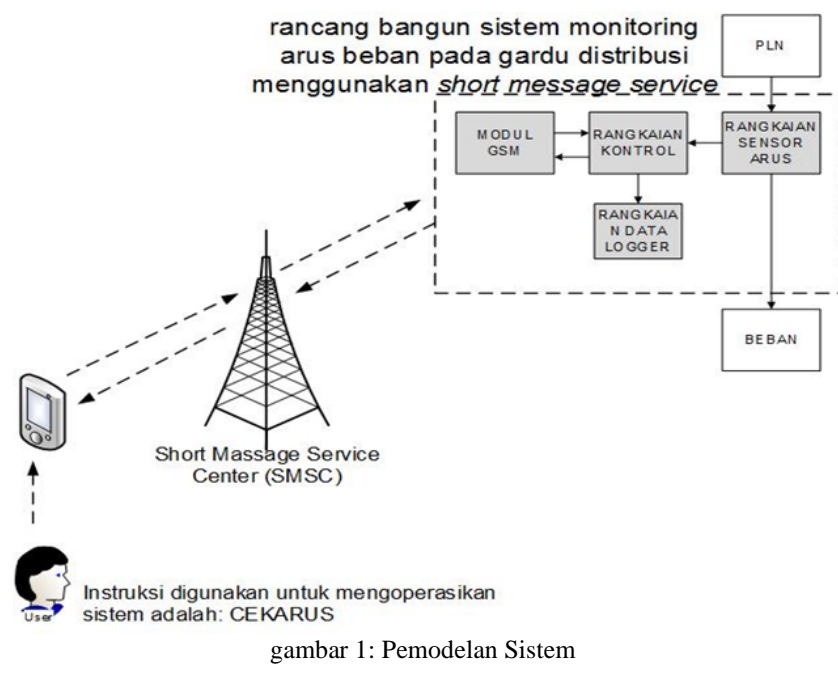

mengirimkan data untuk dikirim kepada user melalui modul GSM. Data yang dikirim adalah instruksi awal serta data yang diperoleh dari hasil pengukuran sensor arus yang telah dikonversi dalam satuan ampere.

4. Pada perancangan terdapat sistem data logger yang dapat digunakan untuk merekam perubahan arus beban per jam.

B. Arduino Mega 2560

Arduino mega 2560 merupakan mikrokontroler berbasis Arduino dengan menggunakan chip ATmega 2560. Arduino mega 2560 memiliki sejumlah 54 buah digital I/O pin, 14 diantaranya adalah PWM, 16 pin analog input, 4 pin UART (serial port hardware). Arduino mega 2560 dilengkapi dengan sebuah osilator kristal $16 \mathrm{Mhz}$, sebuah port USB tipe B, power jack DC, ICSP header, dan tombol reset [3].

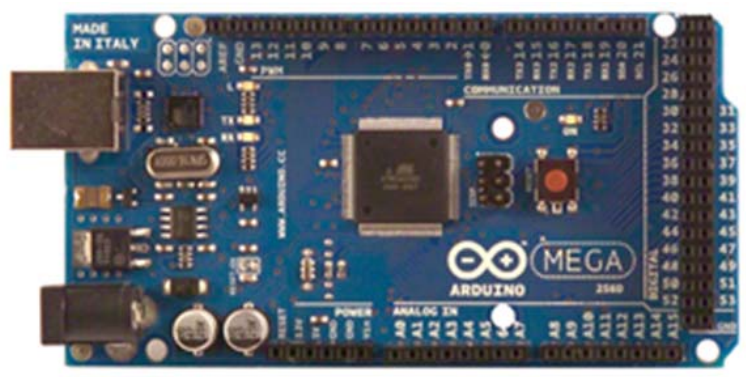

Gambar 2: Arduino Mega 2560

\section{Modul IComSat v1.1-SIM900 GSM GPRS}

IComSat v1.1-SIM900 GSM GPRS merupakan sebuah modul GSM yang diproduksi Iteadstudio. IComSat dapat digunakan menerima serta mengirim data menggunakan layanan pesan singkat [4]. Modul GSM ini dikontrol menggunakan AT Command dan sudah compatible dengan board arduino dan berfungsi menggantikan sebuah handphone dalam hal pengiriman dan penerimaan pesan singkat / SMS [2].

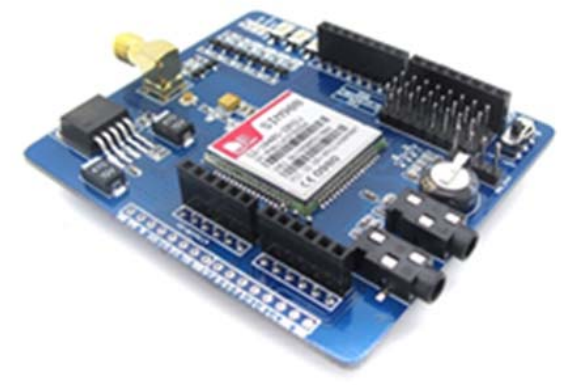

Gambar 3: IComSat v1.1-SIM900 GSM GPRS

\section{Modul Micro SD Card}

Modul micro SD card adalah modul pembaca micro $S D$ card melalui sistem file SPI antarmuka driver, MCU untuk melengkapi sistem file untuk read dan write micro $S D$ card. Modul micro SD card memliki 6 buah pin (GND, VCC, MISO, MOSI, SCK, CS).

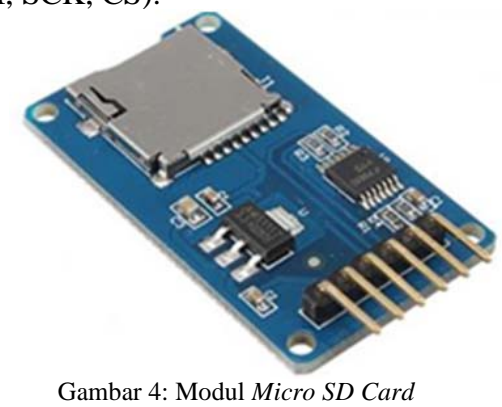

\section{E. Modul RTC (Real Time Clock)}

Modul RTC (Real Time Clock) adalah modul yang menggunakan chip DS1307 serial dengan protokol komunikasi $\mathrm{I}^{2} \mathrm{C}$ (Inter-Integrated Circuit). Fungsinya adalah sebagai penyimpan data waktu digital yang dapat diakses oleh mikrokontroler [7]. Pada perangkat ini modul RTC akan dijadikan sebagai komponen utama pada sistem penunjukan tanggal dan waktu.

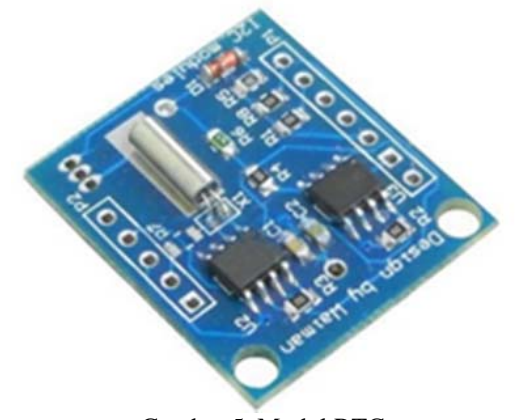

Gambar 5. Modul RTC

F. Sensor Arus YHDC SCT 013-000 1V

Splilt-core Current Transformer adalah sensor arus yang menggunakan konsep cara kerja trafo arus. Transformator arus dirancang untuk mendapatkan nilai arus sekunder yang lebih kecil dibandingkan sisi primernya sehingga aman untuk dilakukan pengukuran. Gambar 6 merupakan jenis trafo arus 
YHDC SCT 013-000 1V dengan batas arus yang diukur sebesar 100 ampere.

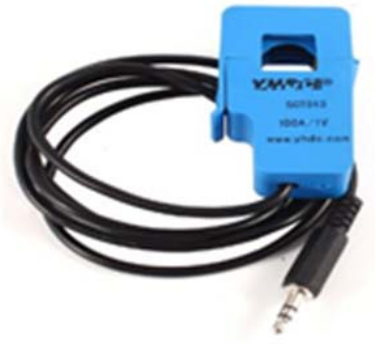

Gambar 6: Sensor Arus YHDC SCT 013-000 1V

\section{G. Perancangan Perangkat Keras}

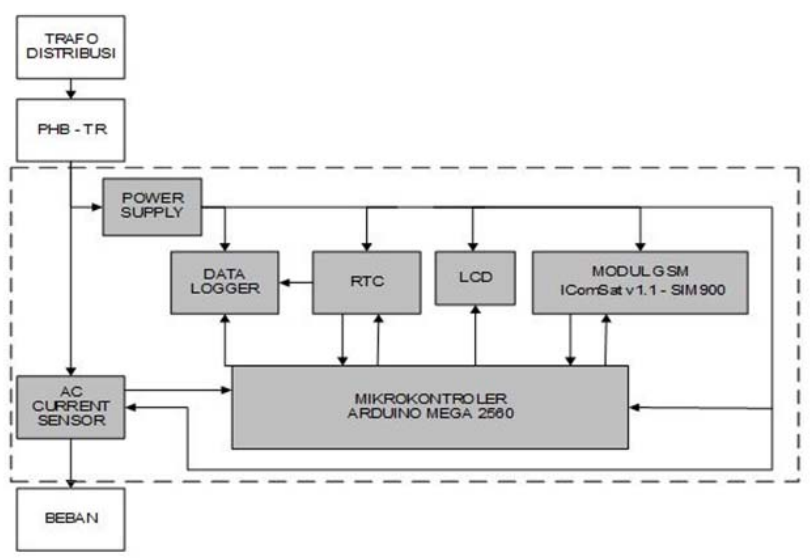

Gambar 7: Blok Diagram Rangkaian

Perancangan hardware dalam pembuatan rangcang bangun sistem monitoring arus beban pada gardu distribuasi menggunakan short message service yaitu:

1. Perancangan rangkaian power supply

2. Perancangan rangkaian mikrokontroler

3. Perancangan rangkaian LCD

4. Perancangan rangkaian RTC (Real Time Clock)

5. Perancangan rangkaian data logger

6. Perancangan rangkaian sensor arus

7. Perancangan rangkaian IComSat v1.1 SIM900 GSM GPRS

8. Perancangan sistem keseluruhan

\section{H. Perancangan Perangkat Lunak}

Perancangan perangkat lunak pada rancang bangun sistem monitoring arus beban pada gardu distribusi menggunakan short message service dengan menggunakan software bawaan dari arduino yaitu Arduino IDE (Integrated Development Environment). Terdapat tiga sub program pada perancangan perangkat lunak yaitu sebagai berikut.

1. Sub program sensor arus

Ignatius I Wayan Rexci Indra Parmana: Rancang Bangun Sistem Monitoring...
2. Sub program modul GSM

3. Sub program data logger

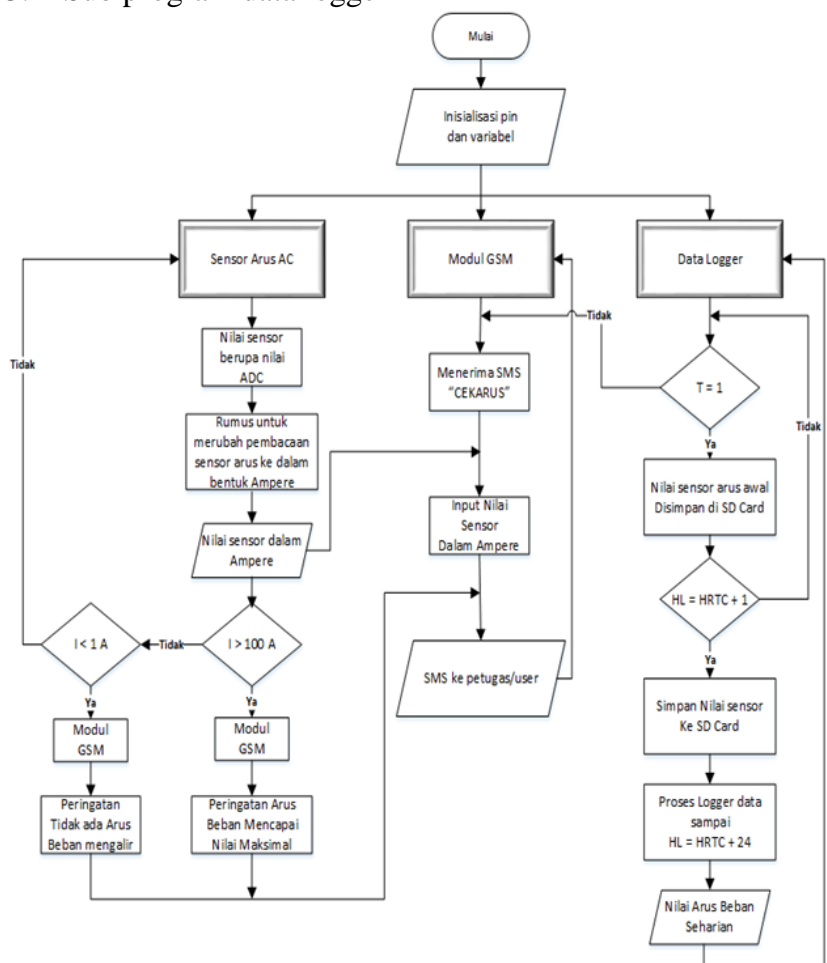

Gambar 8: Diagram Alir (Flowchart) Program Utama

Dari gambar 8 dapat dilihat alur program dari rancang bangun sistem monitoring pada gardu distribusi menggunakan short message service yaitu sebagai berikut.

1. Melakukan inisialisasi pin dan variabel yang digunakan.

2. Sub program sensor arus akan mengolah input pulsa yang dihasilkan sensor arus YHDC SCT 013-000 1V kemudian dikonversikan dalam satuan A (Ampere).

3. Sub data logger akan berjalan secara otomatis setiap jam dan menyimpan hasil pembacaan sensor arus AC ke dalam media penyimpan micro SD card.

4. Data logger akan terus menyimpan secara otomatis hasil pembacaan sensor arus AC setiap jamnya sehingga akan menghasilkan data perubahan arus beban pada gardu distribusi setiap jam.

5. Sub program modul GSM akan melakukan verifikasi jenis kode atau perintah yang dikirimkan melalui pesan singkat.

6. Jika jenis kode adalah CEKARUS maka modul GSM akan mengirimkan SMS hasil pembacaan sensor arus dalam satuan A (Ampere). Jika kode yang dikirimkan tidak sesuai dengan kode yang telah ditentukan maka akan dilakukan verifikasi kembali.

7. Modul GSM akan mengirimkan SMS peringatan jika pada pembacaan sensor arus menunjukkan tidak adanya arus yang mengalir ( $\mathrm{I}<1 \mathrm{~A})$.

8. Modul GSM akan mengirimkan SMS peringatan jika pada pembacaan sensor arus menunjukkan arus beban

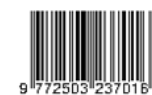


mencapai batas arus maksimum yang ditentukan (dalam penelitian ini I maksimum > 100 A).

\section{HASIL DAN PEMBAHASAN}

\section{A. Hasil Perancangan}

Realisasi rancang bangun sistem monitoring arus beban pada gardu distribusi menggunakan short message service ditunjukkan pada gambar 9 .

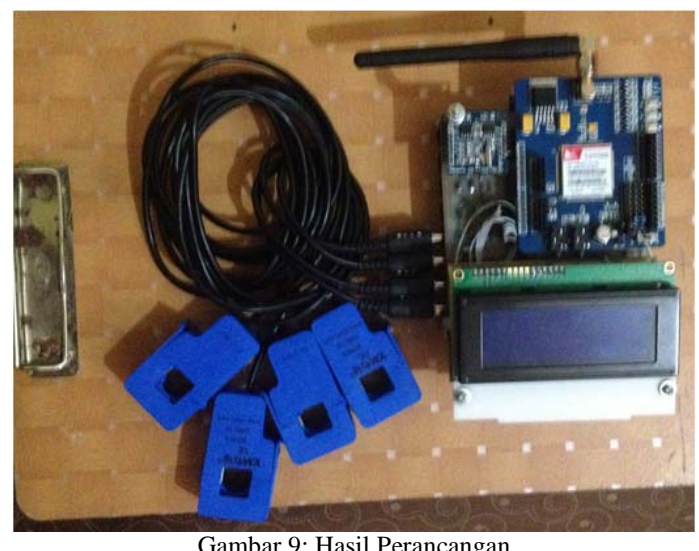

B. Pengujian dan Pembahasan Rangkaian Power Supply

Pengujian dan pembahasan rangkaian power supply dibagi menjadi dua yaitu sebagai berikut.

1) Pengujian Stabilitas Tegangan : dilakukan untuk mengetahui bagaimana pengaruh beban yang diberikan rangkaian mikrokontroler, rangkaian RTC, rangkaian data logger, rangkaian sensor arus, rangkaian LCD dan modul GSM terhadap tegangan keluaran rangkaian power supply. Dalam rangkaian power supply menggunakan dua buah IC regulator yaitu LM7805 dan LM7809. Hasil pengujian stabilitas tegangan ditunjukkan pada tabel 1 .

TABEL I

HASIL PENGUJIAN STABILITAS TEGANGAN

\begin{tabular}{|c|c|c|c|c|}
\hline No & IC Regulator & Kondisi & Hasil Ukur & Error \\
\hline \multirow{2}{*}{1} & \multirow{2}{*}{ LM7805 } & Tanpa Beban & $5,00 \mathrm{~V}$ & $0 \%$ \\
\cline { 3 - 5 } & & Berbeban & $4,98 \mathrm{~V}$ & $0,4 \%$ \\
\hline \multirow{2}{*}{2} & \multirow{2}{*}{ LM7809 } & Tanpa Beban & $8,98 \mathrm{~V}$ & $0,2 \%$ \\
\cline { 3 - 5 } & & Berbeban & $8,98 \mathrm{~V}$ & $0,2 \%$ \\
\hline
\end{tabular}

Referensi [6] menunjukkan bahwa toleransi tegangan keluaran dari IC LM78XX yang diijinkan adalah $\pm 4 \%$ [6]. Dari hasil pengujian yang dilakukan pada IC LM7805 san LM7809 dalam keadaan tanpa beban maupun berbeban dalam keadaan normal. Penyimpangan nilai tegangan keluaran dapat diakibatkan oleh adanya nilai toleransi tegangan pada komponen yang digunakan.

2) Pengujian Konsumsi Daya Listrik : dilakukan untuk mengetahui besarnya konsumsi daya listrik dari perangkat yang direlisasikan yaitu rancang bangun sistem monitoring arus beban pada gardu distribusi menggunakan short message service. Pengujian konsumsi daya listrik dilakukan dengan melakukan pengukuran nilai tegangan dan arus yang mengallir pada rangkaian. Hasil pengujian konsumsi daya listrik ditunjukkan pada tabel 2.

TABEL II

HASIL PENGUJIAN KONSUMSI DAYA LISTRIK

\begin{tabular}{|l|l|c|}
\hline No. & \multicolumn{1}{|c|}{ Besaran } & Hasil Pengukuran \\
\hline 1. & Tegangan & $215,0 \mathrm{~V}$ \\
\hline 2. & Arus & $0,01731 \mathrm{~A}$ \\
\hline 3. & Daya & $3,72 \mathrm{~W}$ \\
\hline
\end{tabular}

Dari hasil pengujian yang dilakukan maka besarnya konsumsi daya listrik yang diperlukan oleh perangkat rancang bangun sistem monitoring arus beban pada gardu distribusi adalah 3,72 W. Gambar 10 menunjukkan pengukuran yang dilakukan saat pengujian konsumsi daya listrik.

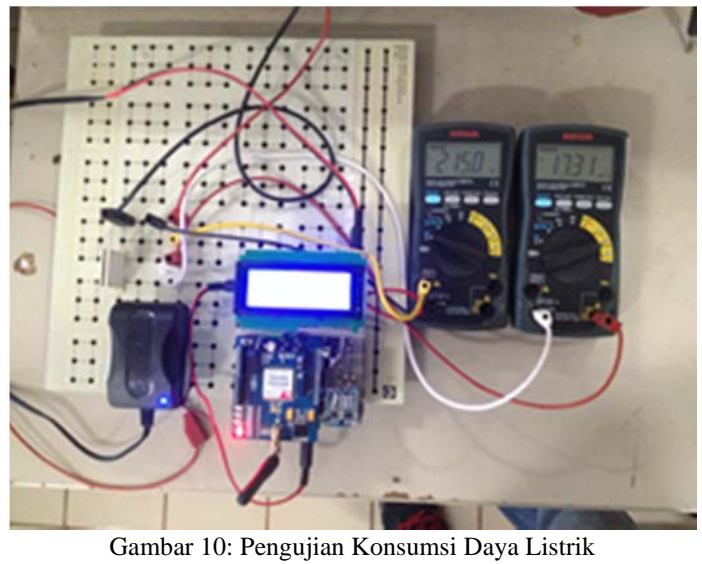

C. Pengujian dan Pembahasan Rangkaian Mikrokontroler dan Rangkaian LCD

Pengujian dan pembahasan rangkaian mikrokontroler dan rangkaian LCD dilakukan untuk mengetahui apakah rangkaian mikrokontroler dan rangkaian LCD bekerja dengan baik sesuai dengan perencanaan. Pada pengujian ini digunakan mikrokontroler Arduino Mega 2560 dan LCD 20x4 sebagai penampil karakter tulisan. Jika karakter pada LCD berhasil ditampilkan makan rangkaian mikrokontroler dan rangkaian LCD berfungsi dengan baik sesuai dengan perencanaan seperti ditunjukkan pada gambar 11 .

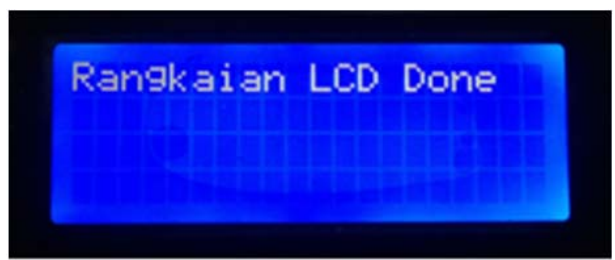

Gambar 11 Hasil Pengujiaan Rangkaian Mikrokontroler dan Rangkaian LCD

\section{Pengujian dan Pembahasan Rangkaian RTC}

Pengujian rangkaian RTC dilakukan untuk mengetahui apakah rangkaian RTC dapat memberikan informasi tanggal dan waktu secara real time. Informasi tanggal dan waktu digunakan sebagai acuan dalam pengiriman SMS dan data logger pada sistem monitoring arus beban. Penguiian 
rangkaian RTC dilakukan dengan membandingkan tampilan tanggal dan waktu pada LCD dengan tampilan tanggal dan waktu pada handphone yang digunakan dalam penelitian seperti ditunjukkan pada gambar 12 .

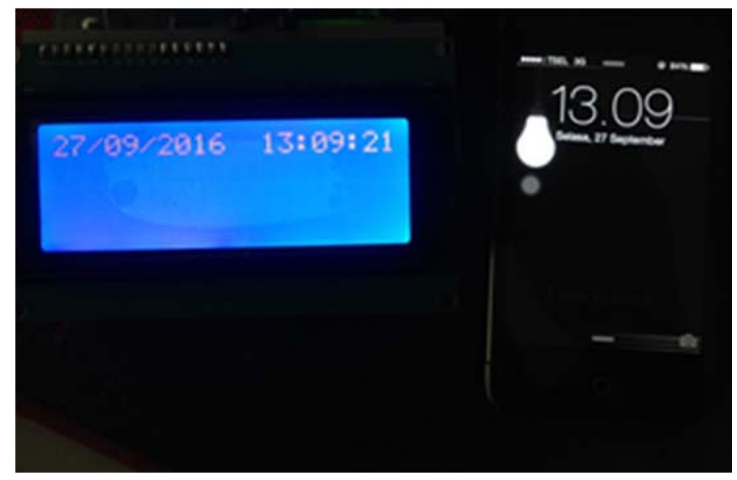

Gambar 12: Hasil Pengujian Rangkaian RTC

Berdasarkan hasil pengujian rangkaian RTC, dapat dikatakan rangkaian RTC sudah bekerja sesuai dengan perencanaan. Hal tersebut dibuktikan dengan perbandingan tampilan informasi tanggal dan waktu pada LCD sudah sesuai dengan tampilan informasi tanggal dan waktu pada handphone yang digunakan.

\section{E. Pengujian dan Pembahasan Rangkaian Data Logger}

Pengujian rangkaian data logger dilakukan unutk mengetahui apakah data logger bekerja dengan baik sesuai dengan perencanaan. Pada pengujian data logger menggunakan modul micro SD card dan menggunakan micro $S D$ card berkaspasitas 2 GB sebagai media penyimpanan data serta menggunakan mikrokontroler Arduino Mega 2560 yang dihubungkan ke PC (Personal Computer) melalui port USB. Pengujian dilakukan dengan cara menulis (write) serta membaca (read) file pada micro SD card. Untuk hasil pengujian dapat dilihat dengan menggunakan fasilitas serial monitor yang disediakan oleh arduino IDE seperti yang ditunjukkan pada gambar 13 .

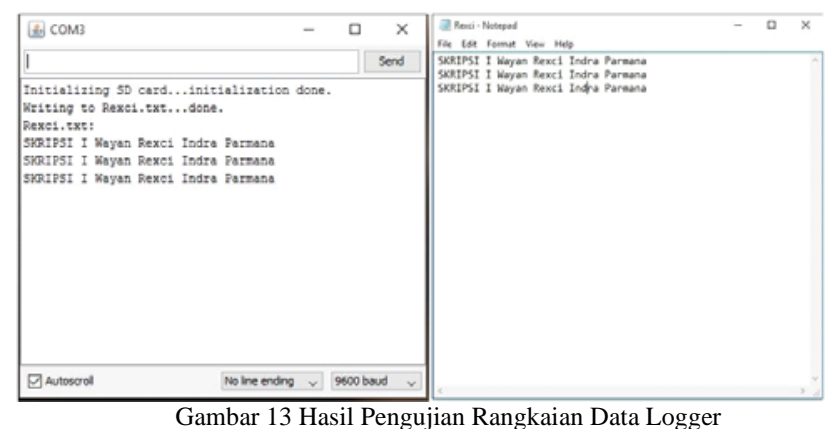

Pada gambar 13 sisi kanan merupakan tampilan fasilitas serial monitor yang ada pada arduino IDE dan pada sisi kiri merupakan file yang terdapat di dalam micro SD card. Berdasarkan hasil pengujian rangkaian data logger menggunakan mikrokontroler arduino 2560, dapat dinyatakan bahwa rangkaian data logger sudah bekerja sesuai dengan perencanaan. Hal tersebut dibuktikan dengan tampilan file yang dibaca serial monitor sesuai dengan file yang ada di di dalam micro SD card.

\section{F. Pengujian dan Pembahasan Rangkaian Sensor arus YHDC SCT 013-000 $1 \mathrm{~V}$}

Pengujian rangkaian sensor arus YHDC SCT 013-000 1 $\mathrm{V}$ dilakukan untuk mengetahui akurasi pembacaan sensor terhadap aliran arus beban yang diukur. Pada proses pengujian dikakukan kalibrasi nilai pembacaan sensor terhadap aliran arus beban sehingga pembacaan nilai sensor arus YHDC SCT 013-000 1 V menjadi akurat. Pada proses pengujian rangkaian sensor arus YHDC SCT 013-000 1 V menggunakan mikrokontroler arduino mega 2560 sebagai pengolah data dengan output tampilan LCD. Output tegangan yang dihasilkan sensor arus akan diproses dan dikonversi mikrokontroler ke dalam satuan A (Ampere) sehingga proses pembacaan nilai sensor arus menjadi prioritas program utama. Hasil pengujian pembacaan nilai sensor arus YHDC SCT 013$0001 \mathrm{~V}$ ditunjukkan pada gambar 14.

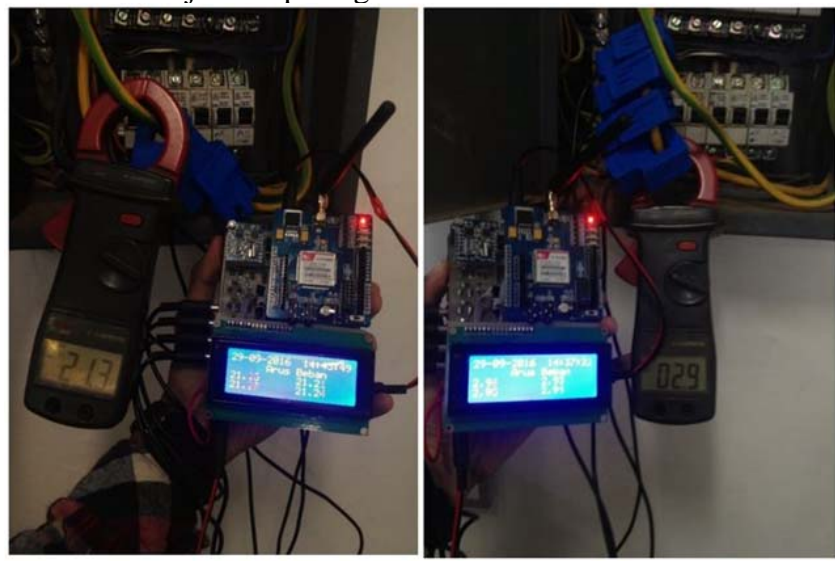

Gambar 14: Hasil Pengujian Rangkaian Sensor Arus YHDC SCT 013-000 1

Pengujian pembacaan nilai sensor arus YHDC SCT 013000 1V dilakukan dua kali pada panel yang berbeda. Pada tabel 3 baris 1 dan 2 merupakan hasil pengujian yang dilakukan pada panel Laboratorium Dasar Teknik Elektro dengan meletakkan semua sensor pada fasa yang sama bertujuan untuk mengetahui perbedaan pembacaan masing masing sensor. Pada tabel 3 baris 3 sampai 6 merupakam hasil pengujian yang dilakukan pada panel utama Kampus Teknik Sudirman. Pengujian dilakukan dengan membandingkan pembacaan nilai arus beban dari sensor arus YHDC SCT 013$0001 \mathrm{~V}$ dengan pembacaan nilai arus beban menggunakan tang ampere konvensional. Tabel 3 merupakan hasil pengujian pembacaan sensor arus YHDC SCT 013-000 1V.

Berdasarkan hasil pengujian sensor arus YHDC SCT 013$0001 \mathrm{~V}$, bahwa rangkaian dan proses kalibrasi sudah berjalan sesuai dengan perencanaan dan jika dirata-ratakan memiiki penyimpangan hasil pembacaan sebesar 0,5\%.

Ignatius I Wayan Rexci Indra Parmana: Rancang Bangun Sistem Monitoring... 


\section{IV. \\ V. SISTEM MONITORING ARUS BEBAN MENGGUNAKAN SMS}

TABEL III

HASIL PENGUJIAN PEMBACAAN NILAI SENSOR ARUS YHDC SCT 013-000 1V

\begin{tabular}{|c|c|c|c|c|c|c|}
\hline \multirow[t]{2}{*}{ No } & \multicolumn{4}{|c|}{$\begin{array}{l}\text { Hasil Pembacaan Sensor Arus } \\
\qquad \text { (A) }\end{array}$} & \multirow{2}{*}{$\begin{array}{c}\text { Hasil } \\
\text { Pada } \\
\text { Tang } \\
\text { Ampere } \\
\text { (A) }\end{array}$} & \multirow[t]{2}{*}{$\begin{array}{c}\text { Error } \\
\text { Pembacaan } \\
\text { Sensor Arus }\end{array}$} \\
\hline & $\mathrm{R}$ & S & $\mathrm{T}$ & $\mathrm{N}$ & & \\
\hline 1 & 21.23 & 21,21 & 21,28 & 21,24 & 21,3 & $0,4 \%$ \\
\hline 2 & 2,96 & 2,93 & 2,95 & 2,94 & 2,9 & $0 \%$ \\
\hline 3 & 59.96 & & & & 59,4 & $0,9 \%$ \\
\hline 4 & & 27,78 & & & 27,6 & $0,6 \%$ \\
\hline 5 & & & 34,73 & & 34,6 & $0,3 \%$ \\
\hline 6 & & & & 21,27 & 21,1 & $0.8 \%$ \\
\hline
\end{tabular}

G. Pengujian dan Pembahasan Modul IComSat v1.1 SIM900 GSM GPRS

Pengujian modul IComSat v1.1 SIM900 GSM GPRS dilakukang untuk mengetahui modul berfungsi dengan baik dalam melakukan pengiriman dan penerimaan perintah melalui SMS. Pengujian dilakukan dengan cara mengirimkan perintah melalui SMS dengan pesan "Hello" ke modul IComSat v1.1 SIM900 GSM GPRS. Jika SMS telah diterima maka secara otomatis modul IComSat v1.1 SIM900 GSM GPRS akan mengirimkan SMS balasan ke user dengan pesan "Hello wayan". Gambar 15 menujukkan hasil pengujian modul IComSat v1.1 SIM900 GSM GPRS yang sudah berfungsi sesuai dengan perencanaan. Hal tersebut ditunjukkan dengan SMS balasan yang dikirim modul IComSat v1.1 SIM900 GSM GPRS yaitu "Hello wayan" ketika handphone yang digunakan mengirimkan SMS "Hello" terlebih dahulu.
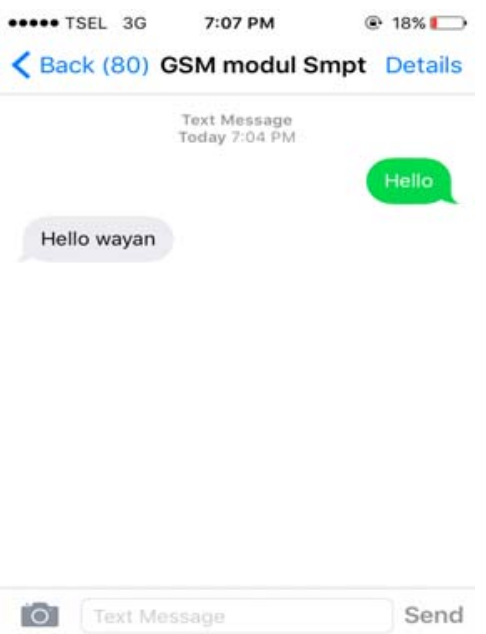

Gambar 15: Hasil Pengujian Modul IComSat v1.1 SIM900 GSM GPRS
Sistem monitoring arus beban menggunakan SMS merupakan perangkat yang dirancang untuk membantu meringankan petugas dalam monitoring arus beban dengan layanan pesan singkat menggunakan jaringan GSM. Pengimplentasian sistem monitoring arus beban ini ditempatkan pada gardu distribusi dengan nomor gardu KA0298 yang berada di Area Kampus Fakultas Teknik Universitas Udayana Bukit Jimbaran. Sistem monitoring arus beban dintegrasikan pada jurusan I gardu distribusi KA-0298 yang menyuplai Laboratorium Teknik Elektro Universitas Udayana seperti ditunjukkan pada gambar 16.

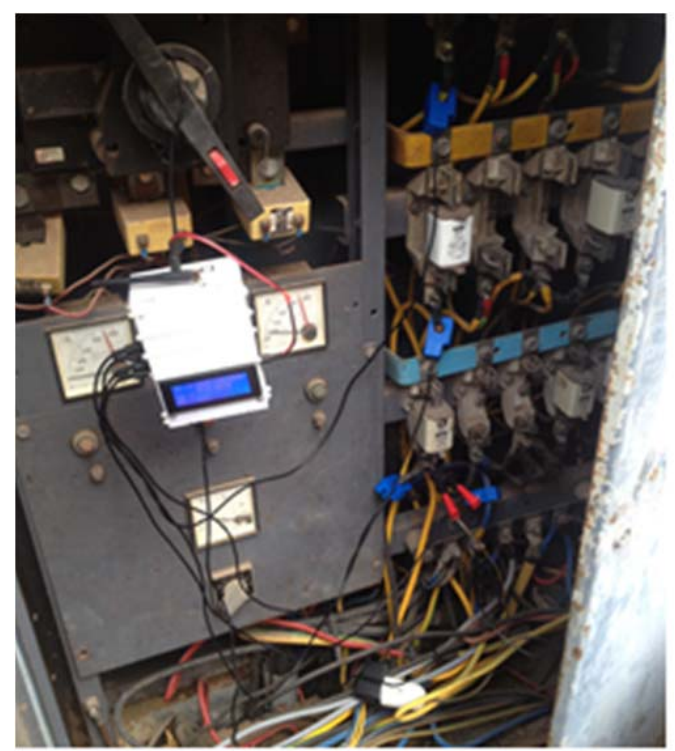

Gambar 16: Penempatan Sistem Monitoring Arus Beban

Pengujian keseluruhan sistem dilakukan untuk mengetahui apakah perangkat sistem monitoring arus beban sudah berjalan sesuai dengan perencanaan. Berikut merupakan beberapa pengujian yang dilakukan.

1. Pengujian pengecekan arus beban menggunakan fasilitas SMS

2. Pengujian SMS notifikasi arus beban

3. Pengujian data logger arus beban

A. Pengujian Pengecekan Arus Beban Menggunakan Fasiltas SMS

Pengujian yang dikakukan dengan mengirimkan SMS dengan kode "CEKARUS" ke perangkat sistem monitoring arus beban dengan nomor yang telah ditentukan. Gambar 17 merupakan tampilan SMS saat handphone yang digunakan petugas mengirim SMS untuk mengetahui informasi arus beban pada gardu distribusi. 


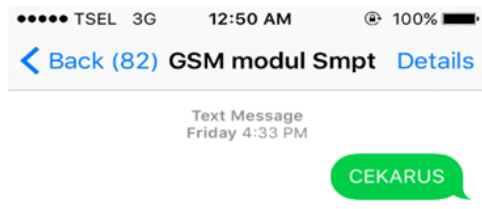

Gext Message
Gambar 17: Tampilan SMS yang Dikirim Petuga

Sistem monitoring arus beban akan secara otomatis merespon jika kode yang dikirim petugas melalui SMS sudah benar. Perintah ini akan diterima modul GSM untuk kemudian akan diolah mikrokontroler. Gambar 18 merupakan respon sistem saat menerima dan mengirimkan SMS informasi arus beban pada gardu distribusi kepada petugas.

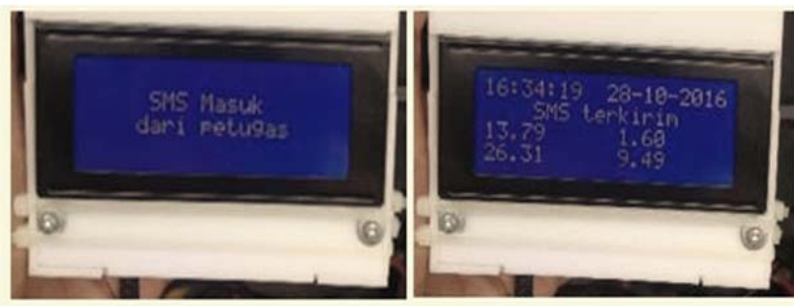

Gambar 18: Respon Sistem Saat Menerima dan Mengirim SMS

Pada LCD terdapat informasi tanggal dan waktu serta respon alat saat menerima dan mengirimkan SMS serta informasi nilai arus beban pada gardu distribusi dalam satuan A (Ampere). Gambar 19 merupakan tampilan SMS balasan yang diterima petugas. Jika dibandingkan dengan tampilan LCD dengan tampilan SMS pada handphone petugas sudah sesuai.

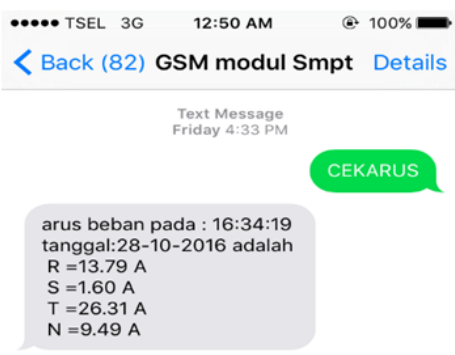

(0) Text Message Send

Gambar 19: Tampilan SMS yang Diterima Petugas

B. Pengujian SMS Notifikasi Arus Beban

Pengujian SMS notifikasi arus beban dilakukan untuk mengetahui respon dari perangkat saat arus beban mencapai nilai batas yang ditetapkan. Keadaan dimana gardu distribusi mengalami gangguan seperti fuse yang putus yang menyebabkan tidak ada arus beban yang mengalir. Sehingga sistem notifikasi ini bertujuan untuk memberi notifikasi kepada petugas saat gardu ditribusi mengalami gangguan arus beban.

Pada proses pengujian dilakukan penyusuaian terhadap kondisi arus beban yang dijadikan acuan pada perangkat sistem monitoring arus beban untuk mengirimkan SMS notifikasi ke petugas. Penyusuaian ini dilakukan untuk efisiensi waktu pada proses pengujian. Pada pengujian SMS notifikasi arus beban dalam keadaan mecapai batas minimal yang ditetapkan dilakukan dengan melepaskan salah satu sensor arus YHDC SCT 013-000 1V dari box panel hubung bagi tegangan rendah pada gardu distribusi sehingga mendapatkan nilai arus beban yang dibutuhkan dalam pengujian. Gambar 20 merupakan tampilan LCD sebagai respon perangkat saat kondisi SMS notifikasi terpenuhi.

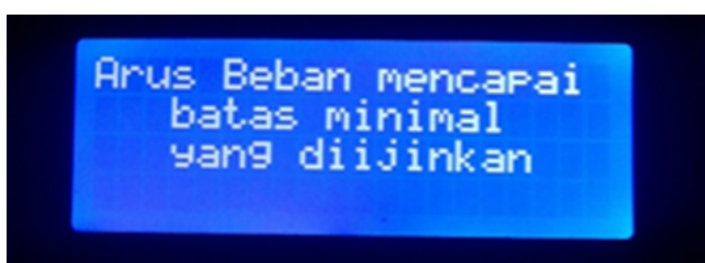

Gambar 20: Tampilan LCD Untuk Respon Perangkat Saat Kondisi SMS Notifikasi Terpernuhi

Kemudian secara otomatis perangkat sistem monitoring arus beban akan mengirimkan SMS peringatan kepada petugas. Tampilan SMS yang diterima petugas ditunjukkan pada gambar 21. 

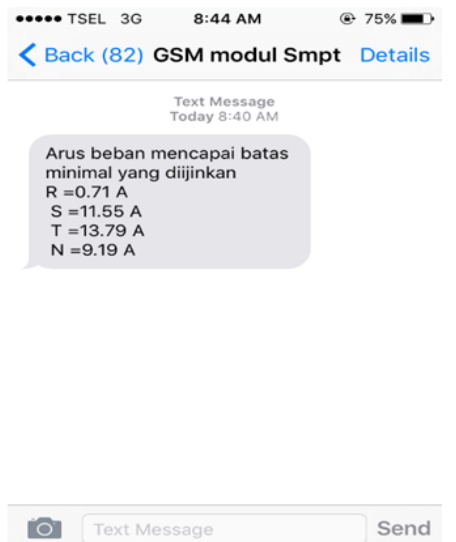

Gambar 21: Tampilan SMS Notifikasi yang Diterima Petugas

\section{Pengujian Data Logger Arus Beban}

Pengujian data logger arus beban dilakukan untuk mendapatkan data perubahan arus beban per jam pada gardu distribusi. Pengujian data logger arus beban dilakukan selama satu hari (24 jam) yaitu dari tanggal 25 Oktober 2016 pada jam 15.00 sampai dengan tanggal 26 Oktober 2016 pada jam 14.00. File hasil pengujian data logger tersimpan pada micro $S D$ card dengan ukuran file sebesar 2,62 KB. Data hasil pengujian ditunjukkan pada tabel 4.

TABEL IV

HASIL PENGUJIAN DATA LOGGER ARUS BEBAN

\begin{tabular}{|c|c|c|c|c|c|c|}
\hline No & Tanggal & Jam & $\begin{array}{c}\mathrm{R} \\
(\mathrm{A})\end{array}$ & $\begin{array}{c}\mathrm{S} \\
(\mathrm{A})\end{array}$ & $\begin{array}{c}\mathrm{T} \\
(\mathrm{A})\end{array}$ & $\begin{array}{c}\mathrm{N} \\
(\mathrm{A})\end{array}$ \\
\hline 1 & $25-08-2016$ & 15.00 & 14,53 & 44,12 & 42,19 & 8,02 \\
\hline 2 & $25-08-2016$ & 16.00 & 8,27 & 19,16 & 17,58 & 8,05 \\
\hline 3 & $25-08-2016$ & 17.00 & 5,94 & 9,84 & 26,45 & 7,65 \\
\hline 4 & $25-08-2016$ & 18.00 & 5,85 & 10,75 & 25,73 & 7,94 \\
\hline 5 & $25-08-2016$ & 19.00 & 5,72 & 11,71 & 18,11 & 7,04 \\
\hline 6 & $25-08-2016$ & 20.00 & 6,08 & 11,85 & 26,88 & 7,41 \\
\hline 7 & $25-08-2016$ & 21.00 & 6,33 & 10,48 & 18,65 & 7,37 \\
\hline 8 & $25-08-2016$ & 22.00 & 6,71 & 10,37 & 26,33 & 6,74 \\
\hline 9 & $25-08-2016$ & 23.00 & 5,87 & 9,50 & 25,79 & 6,70 \\
\hline 10 & $26-08-2016$ & 00.00 & 7,92 & 9,61 & 17,19 & 6,74 \\
\hline 11 & $26-08-2016$ & 01.00 & 5,92 & 9,40 & 16,98 & 6,54 \\
\hline 12 & $26-08-2016$ & 02.00 & 6,75 & 9,50 & 25,38 & 6,57 \\
\hline 13 & $26-08-2016$ & 03.00 & 14,55 & 10,31 & 16,15 & 6,97 \\
\hline 14 & $26-08-2016$ & 04.00 & 5,95 & 10,22 & 16,39 & 6,47 \\
\hline 15 & $26-08-2016$ & 05.00 & 15,15 & 10,18 & 19,46 & 7,06 \\
\hline 16 & $26-08-2016$ & 06.00 & 5,59 & 10,26 & 8,58 & 7,29 \\
\hline 17 & $26-08-2016$ & 07.00 & 14,53 & 10,10 & 6,65 & 7,76 \\
\hline 18 & $26-08-2016$ & 08.00 & 8,01 & 10,30 & 16,98 & 7,33 \\
\hline 19 & $26-08-2016$ & 09.00 & 9,49 & 10,25 & 16,33 & 7,39 \\
\hline 20 & $26-08-2016$ & 10.00 & 9,51 & 16,15 & 43,23 & 7,60 \\
\hline 21 & $26-08-2016$ & 11.00 & 9,44 & 31,45 & 33,46 & 7,94 \\
\hline 22 & $26-08-2016$ & 12.00 & 9,87 & 19,93 & 33,64 & 8,03 \\
\hline 23 & $26-08-2016$ & 13.00 & 10,00 & 18,18 & 35,65 & 8,09 \\
\hline 24 & $26-08-2016$ & 14.00 & 9,92 & 18,72 & 36,79 & 8,33 \\
\hline$B$
\end{tabular}

Berdasarkan tabel 4 didapatkan grafik perubahan nilai arus beban per jam pada gardu distribusi selama satu hari ditunjukkan pada gambar 22.

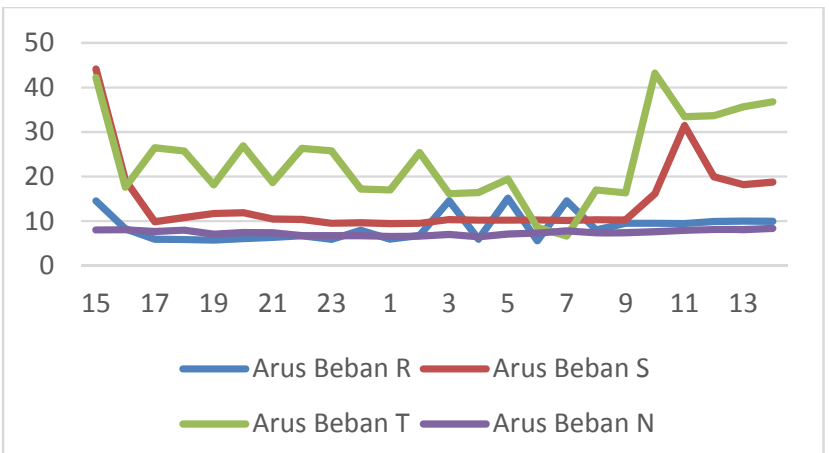

Gambar 22: Grafik Data Logger Perubahan Nilai Arus Beban pada Gardu Distribusi Selama Satu Hari

\section{KESIMPULAN}

Rancang bangun sistem monitoring arus beban pada gardu distribusi menggunakan short message service dapat diimplementasikan dengan baik pada gardu distribusi KA0298 mengunakan sensor arus YHDC SCT 013-000 1V dengan rata-rata penyimpangan $0,5 \%$. SMS informasi nilai arus beban pada gardu distribusi telah berhasil diterima dan dikirim oleh perangkat sesuai dengan informasi pembacaan sensor dan informasi waktu yang ditetapkan pada perangkat. Sistem notifikasi arus beban memberikan SMS peringatan dengan menggunakan nilai arus beban sebagai acuan. Sistem data logger dapat digunakan untuk merekam perubahan arus beban per jam serta mengetahui waktu beban puncak pada gardu distribusi.

\section{REFERENSI}

[1] Firmansyah R. A., SuheraT., Antoni D. 2015. "Perancangan Alat Monitoring dan Penyimpan Data pada Panel Hubung Bagi Tegangan Rendah Berbasis Mikrikontroler”. Surabaya: Institut Teknologo Ahi Tama Surabaya.

[2] Pradnyana G. 2016. "Sistem Kontrol Daya Listrik pada Saluran Masuk Pelayanan Tenaga Listrik Menggunakan Short Message Service”. Jimbaran: Universitas Udayana; 2016.

[3] “Arduino Mega 2560 data sheet," Arduino ${ }^{\mathrm{TM}}$.

[4] “IComsat v1.1 SIM900 GSM GPRS data sheet,” ITead Studio.

[5] Achyat M. B. P., Priandana K. 2014. "Rumah Pintar Berbasis Pesan Singkat dengan Menggunakan Mikrokontroler Arduino”. Bandung: Institut Pertanian Bogor; 2014.

[6] “LM78XX data sheet,” Unisonic Technologies.

[7] “DS1307 I2C RTC 24C32 Module data sheet”.

[8] Paramarta P. M. N 2016. "Rancang Bangun Pendeteksi Kebocoran LPG Menggunakan Sensor TGS2610 Dilengkapi SMS Berbasis Mikrokontroler ATmega328”. Denpasar: Universitas Udayana; 2016. 